\title{
Assessment of governance of fisher communities of inland openwater fisheries in Bangladesh
}

\begin{abstract}
The Community Based Fisheries Management (CBFM) with partnership arrangement of government, non-government organisations, fisher communities and other stakeholders has introduced community management of inland openwater fisheries in Bangladesh. This arrangement introduced CBFM approaches named fisher-led, community-led and women-led approach. One of the principles behind community based managed fisheries is to improve democratisation process of changing governance of fisheries aiming to manage their resources efficiently. The CBFM approach has made a significant contribution towards improvement of governance and democracy to fisher communities. Besides, a wider range of local institutional arrangements as community based organizations (CBOs) have been established through participatory process with legal entity. Now, there is practice of governance and democracy within CBOs and fisher communities. They are more efficient in participation of fisheries management. This paper presents and assesses the governance status of the fisher communities in inland openwater fisheries under co-management arrangement in Bangladesh. In summary, it might recommend at policy level to scale up community based fisheries approach to promote governance for better management with a long term commitment.
\end{abstract}

Keyword: Fisheries management; Governance approach; Inland openwater fisheries 